\title{
STAFF DEVELOPMENT STRATEGIES AND ORGANIZATIONAL PERFORMANCE: A STUDY OF NIGERIAN AGIP OIL COMPANY LIMITED, PORTHARCOURT, RIVERS STATE
}

\author{
${ }^{1}$ Dom-Nwachukwu Ijeoma Hossana, ${ }^{2}$ B. Chima Onuoha \\ ${ }^{1}$ University of Port Harcourt Business School, Port Harcourt Rivers State. \\ ${ }^{2}$ Department of Management, Faculty of Management Sciences, University of Port Harcourt, Choba.
}

Article DOI: https://doi.org/10.36713/epra7503

DOI No: 10.36713/epra7503

\begin{abstract}
This study investigated the relationship between staff development strategies and organizational performance. The independent variable, Staff development had as its dimension, coaching and mentoring, while the dependent variable organizational performance was measured using growth. The study adopted the cross sectional survey method of the quasi experimental research design. The study has a population of 1350 staff of NAOC studied, a sample of 271 from the population was taken using the Krejcie and Morgan sample size determination table. The questionnaire was the main instrument used to gather primary data, the instrument was subject to face and content validity, a pilot study was also carried out to ensure the instrument measures what it sets out to measure. A reliability of the instrument was also done using the Cronbach alpha test. The Spearman's Rank Order Correlation Coefficient was used to test the hypotheses, while the partial correlation was used to check the effect of the moderating variable on the dependent and independent variable. Our findings revealed a significant relationship between the dimensions of our independent variable staff development strategies given as coaching and mentoring, and the measures of the dependent variable given as growth. It also concluded that coaching and mentoring play significant roles in building effective organizations. The study recommended that organizational practices be streamlined to increase coaching and mentoring by assigning or encouraging leaders to adopt subordinates and assign higher responsibilities aimed at seeing them develop.
\end{abstract}

KEYWORDS: Staff development strategies, organizational performance, mentoring, coaching and organizational growth.

\section{INTRODUCTION}

Organizational performance is one of the most complex and least tackled problems in the study of social organizations. Many difficulties arise with attempts to define the concept of performance adequately. Some stem from the association of the concept with the question of values (e.g., "management" versus "labour" orientations). Other problems arise when researchers choose a priori criteria of performance that seem intuitively right, without trying systematically to place them within a consistent and broader framework. In effect, specific criteria that might be proper in one organization may be entirely inappropriate to other organizations. The question arises whether it is possible to develop a definition of performance and to derive criteria that are applicable across organizations and can be meaningfully placed within a general conceptual framework Ulrich (2011).

We define organizational performance as the extent to which an organization as a social system, given certain resources and means, fulfills its objectives without incapacitating its means and resources and without placing undue strain upon its members (Salas \& Cannon-Bowers, 2001). This conception of performance subsumes the following general criteria: organizational productivity, organizational flexibility in the form of successful adjustment to internal organizational changes and successful adaptation to 
externally induced change; and, absence of intra organizational strain, or tension, and of conflict between organizational subgroups. These three criteria both relate to the means ends dimension of organizations and, potentially, apply to nearly all organizations Wang (2001). The first relates to the movement of the organization toward its goals (locomotion); the others relate to the requirements of organizational survival in the face of external and internal variability, and to the dimension of preservation (or incapacitation) of organizational means. In an attempt to evaluate the present approach, we have used these criteria in the study of a large-scale organization, which we feel is particularly suitable to our investigation because of the simplicity of its structure Liu (2002).

Staff development refers to the obtaining or transferring knowledge, skills and abilities (KSA) process needed to carry out a specific activity or functions; so, the benefits of training and development both for organization and individual are strategic in nature and hence much wider. To meet the current and future challenges of organizations', training and development assume a wide range of learning actions, ranging from training of the individual for their present tasks and moreover, knowledge sharing to improve the organization horizon and customers service, which focus on their career development and enrichment, thus expanding individual, group and organizational performance (Niazi, 2011). According to the dynamic developments of all work fields, the organization must develop their HR to strategic HR, because organizations cannot apply a strategic training plan unless they have a strategic human resource management system in place. In the strategic human resource management literature, strategic training is regarded as a vital way of raising employee efficiency (Richard et al., 2009). HRM is a way of connecting the human resource function with the strategic goals of the organization in order to raise productivity (Bratton, 2003). Although financial return from training is difficult to determine, it can be measured in some instances. However, the evaluation of training is carried out not only in money terms, but also in terms of people, work, and power. A comprehensive assessment of training outcomes also involves assessing trainee reactions, its impact on the workplace, operating and financial outcomes, and its perceived usefulness in assisting people to carry out changes. In addition to that, theories help us understand the real world by creating the relationships between the different aspects from the theorist's perspective (Dubin, 1976:26).

Aims and Objectives:

To establish the relationship between staff development strategies and organizational performance.
To investigate the relationship between coaching and organizational growth.

To ascertain the relationship between mentoring and organizational growth.

\section{LITERATURE REVIEW THEORETICAL REVIEW THE UNIVERSALISTIC THEORY}

This is recounted with the term "best practice" and "high performance work practices", and its underlying assumptions or arguments may seem somewhat simplistic: i That there is a linear relationship between human resource practices or systems and organizational performance. ii. That best practices are universally applicable and successful. iii. That organizational success is best measured in terms of financial performance indicators like profits, or by market share and sales levels. Osterman Pfeffer and Huselid (2009) may be taken to represent those who bear universalistic perspective. Proponents of universalistic theory believe that there is a universal practice to be remained with HRM. It is the best practice that any organization can adopt it anywhere and these proponents are against using culture, environment, heterogeneity of people and their behaviour. Therefore, it is better if those proponents are classified as Universalists and their ideology is as 'universally best practice theory or universalistic theory of HRM. From the above argument one may deduce that attempts are made to standardize the model so that its universalistic application is envisioned.

\section{SOCIAL EXCHANGE THEORY}

Exchange theorists advance a basic image of social structure as a configuration of social relations among actors (both individual and corporate), where the relations involve the exchange of valued items (which can be material, informational, symbolic, etc). Exchange theory has increasingly involved explicit consideration of social structure, as both product and constraint, typically in the form of networks of social relations. We will comment on the similarities and differences in the perspectives on social structure of three of the principal exchange theorists in historical progression.

\section{HOMANS VIEW OF SOCIAL STRUCTURE}

Homans' View of Social Structure, Homans' (1961, 1964) primary purpose was the study of the "sub institutional" or "elementary" forms of behaviour. Homans developed a theory of social behaviour based primarily upon behavioral principles of analysis. He took as the domain of his explanatory framework (1961), "the actual social behaviour of individuals in direct contact with one another." He refers to this 
behaviour as elementary and clearly distinguishes it from behaviour that can be defined as obedience to the norms of a society (including role-related behaviour). Role-conforming behaviour was institutionalized behaviour, thus actual behaviour was defined by Homans as sub institutional. For Homans, social structures emerge from elementary forms of behaviour and change over time in response to changes in this behaviour by aggregates. (He does not address in any detail the complex interplay between micro level processes and aggregate level outcomes.) He argued that the similar behaviours of enough people can alter existing social structures and institutions and even, under some conditions, replace them. "Sometimes the great rebellions and revolutions, cracking the institutional crust, bring out elementary social behaviour hot and straight from the fissures" (Homans 1961:398). His analysis of social behaviour endures as a classic in sociology precisely because his vision of the underpinnings of social structure and institutional forms is straight forward and is linked so clearly to the actions of individuals (i.e. to their responses to rewarding and punishing circumstances).

\section{CONCEPTUAL FRAMEWORK}

\section{Fig. 1.1 Conceptual Framework}

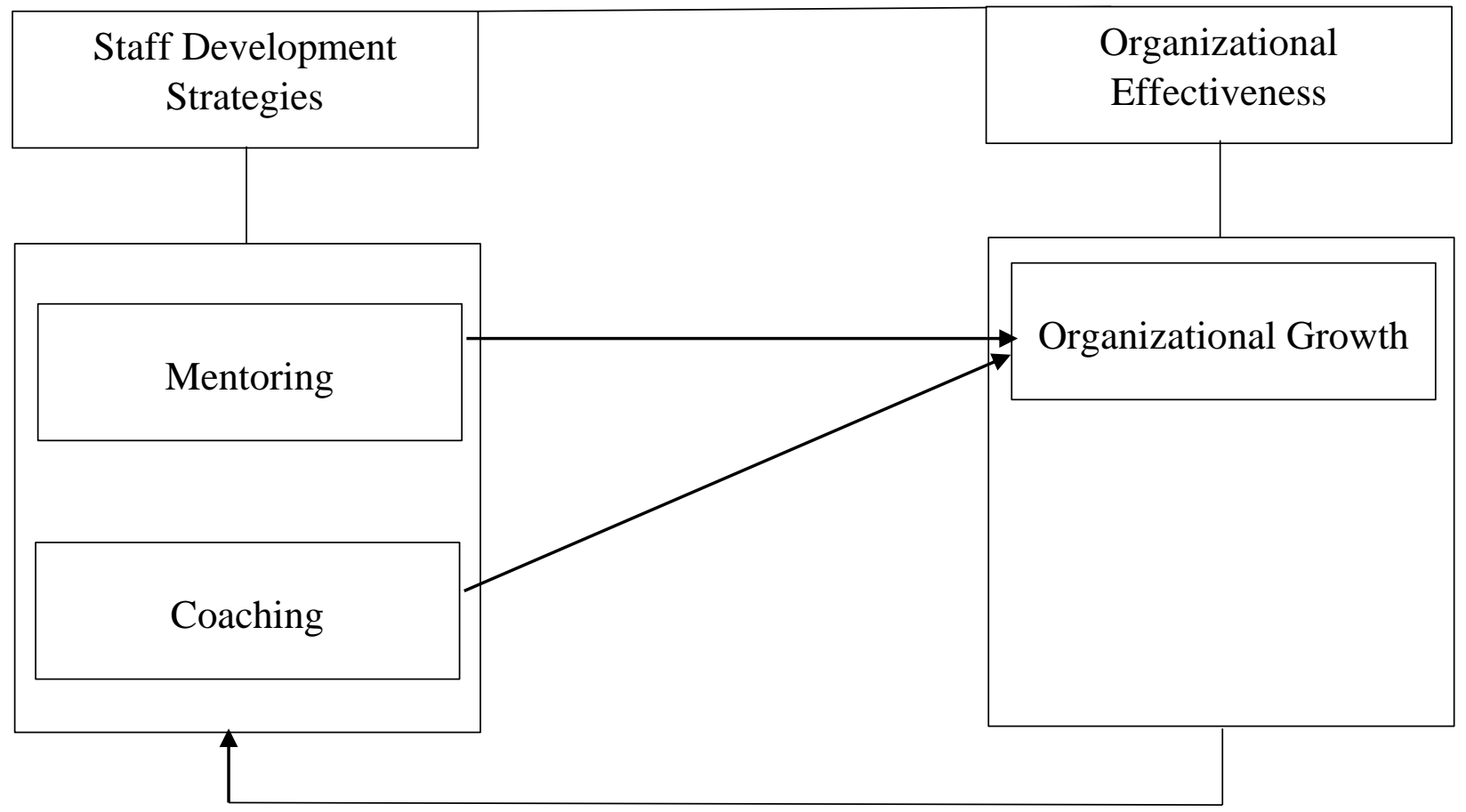

Source: the dimensions of our independent variables (mentoring and coaching) were adapted from the work of (Ulrich, 2011) while the measure of the dependent organizational growth was adopted from the work of Bratton and Gold, (2007)

\section{STAFF DEVELOPMENT STRATEGIES}

Staff development is defined as "a planned process to modify attitude, knowledge, skill or behavior through learning experience to achieve effective performance in an activity or range of activities. Its purpose, in the work situation, is to develop the abilities of the individuals and to satisfy the current and future needs of the organization" (Manpower Services Commission, 1981, p. 62 in Wilson, 1999, p. 4). Beardwell and Holden (2001) stated that training is a planned process that is used to change attitudes, knowledge, skills and behavior through the learning experience in order to achieve effective performance in a specific activity or range of activities. Its purpose, in 
the work context, is to develop the abilities of individuals and to satisfy the current and future needs of the organization. This definition links training and planning process with training as a planned operation aimed at modifying skills through the application of experience and education. Training is an ongoing planned process that replicates many of the stages involved in the task in order to achieve the intended benefit. Bratton and Gold (2007, p. 197) define Human Resource (HR) planning as 'the process of systematically forecasting the future demand and supply for employees and deployment of their skills within the strategic objectives of the organization'. According to Werner and DeSimone (2006, p. 10), HR planning helps companies predict how changes in their strategy will affect their HR needs.

\section{TRAINING}

Any institution of higher learning or business whose goals are to survive and prosper in this present day diverse and regressed economy has found it imperative to invest in ongoing training and development to improve proficiencies in production as well as to acquire the greatest return on investment of human capital (Knoke and Kalleberg, 1994). Although this area of training performance seems paramount, and although training is an integral part of the employeremployee relationship, (Knoke and kalleberg, 1994) suggest that direct evidence about company training practices based on representative samples of diverse employing organizations is almost non-existent. Furthermore, several authors have suggested that training is most extensive only in establishments which operate in complex market environments. (Rowden and Conine, 2005; Sahinidis and bouris, 2008). In addition, (Rowden and Conine, 2005; Sahinidis and Bouris, 2008) indicated that there is limited research on human resource development in small and midsized business. According to these authors, most people believe that small business do little, if any, in the development of their workers. Moreover (Rowden and Connie, 2005) said that their training organization which is into workers training in the United States have not tried to contact firms with less than one hundred employees. In addition, in their annual research sample, only $16 \%$ consisted of companies between 100 and 500 workers. In general, little human resource development occur in small business (Hill and Stewart, 1999). In summary a slow growing number of authors are currently doing more research in the areas of training and development and its effects on employees that we have not seen in past literatures.

\section{CONCEPT OF ORGANIZATIONAL PERFORMANCE}

Organizational performance remains a preeminent concept among management scholars and practitioners and this is traceable to the fact that it is a critical attribute of all organizations notwithstanding their type, size, and age. From the perspective of the practitioner, organizational performance is a desirable organizational attribute which guarantees a firm's survival and continued support by stakeholders. Effective organizations are usually described as healthy, successful, productive, excellent, high performance organization and full of vitality. Drucker (1977) defines performance as doing the right things. Organizational performance, according to Etzioni (1964) is the degree to which an organization realizes its goals. But Seashore and Yuchtman (1967) see it as the ability of the organization to exploit the environment in the acquisition of critical resources to sustain its functioning. On his part, Price (1968) defines $\mathrm{OE}$ as the degree of goal achievement. Such goals include profit, productivity, return on asset, sales growth, etc. Richard, Devinney, Yip and Johnson (2009) argue that OE captures organizational performance plus the myriad of internal performance outcomes normally associated with more efficient or effective operations and other external measures that relate to considerations that are broader than those simply associated with economic valuation (either by shareholders, managers or customers) such as corporate social responsibility. Similarly, Mihalicz (2012) observes that organizational performance is far more than the ability of a company to make sales or to turn a profit; rather, it focuses on the overall performance in these short-term areas, as well as sustainability, concern for the environment, corporate culture, talent management, leadership, innovation, strategy, engagement, and communication.

\section{CORPORATE GROWTH}

Organizational growth is a major concern to managers, scholars and even the government and this is due to the fact that it has serious implications for firm survival, aggregate employment and economic growth. As a matter of fact, Weinzimmer, Nystrom \& Freeman (1998) argue that organizational growth is inherently a dynamic measure of change overtime. It shows how an organization has managed change whether planned or externally imposed. It is a pointer to a firm's effective adaptation to the environment. Ordinarily, organizational growth is defined as an increase in certain attributes such as sales, employment and/or profit of a firm between two points in time (Hakkert \& Temp, 2006). Nelson \& Winter (1982) define it as an organizational outcome resulting from the combination 
of firm specific resources, capabilities and routines. A number of parameters have been identified for measuring organizational growth such as financial or stock market value, number of employees, sales, asset, production capability, value of production or added value of production (Ardishvili, Cardozo, Harmon \& Vadakath, 1998; Kimberly, 1976).

$\mathrm{HO}_{1}$ : There is no significant relationship between coaching and growth.

$\mathrm{HO}_{2}$ : There is no significant relationship between mentoring and growth.

\section{EMPIRICAL REVIEW}

Ronald and Christopher, (2003) examines the relationship between employee development and organizational performance. The research supports the commonly held belief that employee development programs make positive contributions to organizational performance. However, there continues to be limited information beyond this basic relationship. From an HRD perspective, research on employee development seems an area of high importance. Employee development means more than helping employees become continuous learners, regardless of the requirements of the organization. To be beneficial for both individual employees and organizations, research on employee development should seek greater understanding about the wide range of conditions within which employee development programs exist in organizations. Undertaking the three proposed research directions would do much for improving organizational performance in the long term.

Abdul and Aemer (2011) examined employee development and its effect on employee performance. Employee is a key element of the organization. The success or failure of the organization depends on employee performance. Therefore, organizations are investing huge amount of money on employee development. This paper analyzes the theoretical framework \& models related to employee development and its effect on employee performance. The key variables identified relates to employee development and employee performance. The further discussion develops a proposed model which explains the relationship between employee development variables (employee learning, skill growth, self-directed, employee attitude) and employee performance variable.
The employee performance will affect organizational effectiveness. The paper is divided into three parts. The introductory part provides brief overview related to employee development and its effect on employee performance. The second part analyzes the views and studies of the past researchers related to employee development and employee performance. In the end, paper presents the proposed model along with the discussion and conclusion

\section{METHODOLOGY}

The study adopted the cross sectional method of the quasi experimental research design. A population of one thousand three hundred and fifty (1350) contract staff of NAOC was obtained for this study, the employees were selected across all departments of the organization. Given the large number of the population, a sample size of two hundred and seventy-one (271) was obtained using the Krejcie and Morgan sample size determination table. Primary data was mainly collected for this work, as a result, the questionnaire was used as the main instrument for data collection. The instrument was subject to construct and content validity, with a pilot study further done to validate the instrument. The reliability was tested using the Cronbach Alpha test at a significance of 0.7 . The hypotheses was tested using the Spearman Rank Correlation Coefficient.

\section{DATA ANALYSIS}

Data analysis is carried out and presentations of the outputs of our data analysis. The analyzed data are presented through frequencies, tables and chart illustrations. Data is analyzed in this chapter in four major phases, namely: the demographic, univariate, bivariate and multivariant phase. The demographic phase covers areas such as gender, age, marital status, and educational qualification, which are used in describing the sample characteristics. The univariate analysis covered a statistical assessment of individual variables through the use of frequency distributions, mean scores and standard deviations. The bivariate phase of analysis is concerned with the test of previously stated hypothetical relationships between variables, while the multivariant analysis covers the relationship between the moderating variables and the individual variables.

Table 4.1 Showing the Outcome of Questionnaire Distribution

\begin{tabular}{|c|c|c|}
\hline $\begin{array}{l}\text { Number of Questionnaire Distributed } \\
\text { Number of Questionnaire Retrieved } \\
\text { Number of Usable Questionnaire }\end{array}$ & $\begin{array}{l}271 \\
246 \\
214\end{array}$ & $\begin{array}{l}100 \% \\
91 \% \\
87 \%\end{array}$ \\
\hline
\end{tabular}




\section{DEMOGRAPHIC ANALYSIS}

A total number of two hundred and seventy-one (271) copies of questionnaire were distributed of which two hundred and forty-six (246) were retrieved and after assessment, two hundred and fourteen (214) copies which were properly filled thus, valid and usable. Others that were not properly filled were discarded as null and void. Analyses are done on the bases of the 214 copies properly filled.

Table 4.2 Distribution on Respondents' Gender

\begin{tabular}{rlr|r|r|r} 
& \multicolumn{3}{c}{ Gender } & & \multicolumn{1}{c}{$\begin{array}{c}\text { Cumulative } \\
\text { Percent }\end{array}$} \\
\hline Valid & Frequency & Percent & Valid Percent & 55.6 \\
\cline { 2 - 6 } & Male & 119 & 55.6 & 55.6 & 44.4 \\
\cline { 2 - 6 } & Female & 95 & 44.4 & 44.4 & \\
\cline { 2 - 6 } & Total & 214 & 100.0 & 100.0 & \\
\hline
\end{tabular}

SPSS output, Version 26

Table 4.2 shows gender distribution of respondents with the higher distribution on male $(55.6 \%)$ followed by their female counterparts (44.4\%).

Table 4.3 Age Distribution of Respondents Age Range

\begin{tabular}{rlr|r|r|r}
\multicolumn{2}{c}{} & \multicolumn{2}{c}{ Age Range } & & \multicolumn{1}{c}{$\begin{array}{c}\text { Cumulative } \\
\text { Percent }\end{array}$} \\
\hline Valid & Frequency & Percent & Valid Percent & 17.3 \\
\cline { 2 - 6 } & $<=30$ Years & 37 & 17.3 & 17.3 & 40.2 \\
\cline { 2 - 6 } & $31-35$ Years & 49 & 22.9 & 22.9 & 66.4 \\
\cline { 2 - 6 } & $36-40$ Years & 56 & 26.2 & 26.2 & 85.0 \\
\cline { 2 - 6 } & $41-45$ Years & 40 & 18.7 & 18.7 & 100.0 \\
\cline { 2 - 6 } & $>=46$ Years & 32 & 15.0 & 15.0 & \\
\cline { 2 - 6 } & Total & 214 & 100.0 & 100.0 &
\end{tabular}

SPSS output, Version 26

Table 4.3 shows age distribution of respondents with the highest distribution on those within the age bracket $36-40$ years $(26.2 \%)$ followed by those within $31-35$

years $(22.9 \%)$, those within $41-45$ years $(18.7 \%)$ and those who are below or equal to 30 years $(17.3 \%)$ and lastly those who are 46 years and above $(15.0 \%)$.

Table 4.4 Distribution on Marital Status of Respondents Marital Status

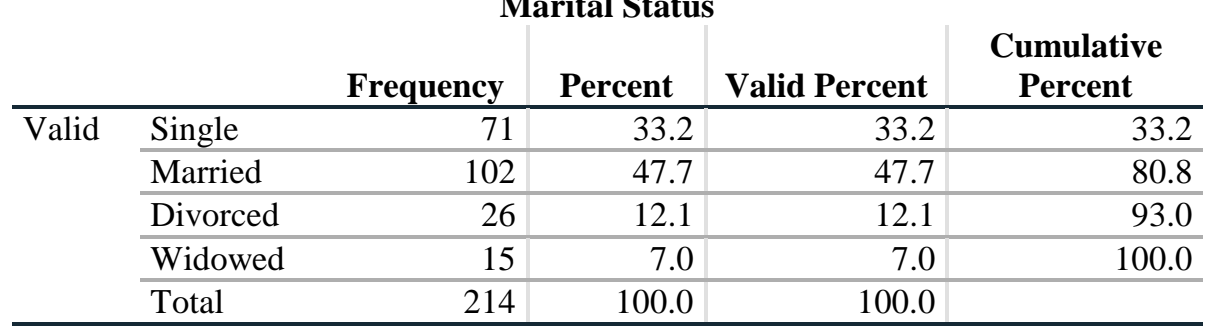

SPSS output, Version 26

Table 4.4 shows distribution on marital status of respondents with the higher distribution on the married employees $(47.7 \%)$ followed by the single employees $(33.2 \%)$. Then the divorced and widowed $(12.1 \%)$ and (7.0\%) respectively.

\section{UNIVARIATE LEVEL ANALYSES}

The univariate analysis was focused on their apparent properties or measures, which included a survey of the distributions of variables. Summaries such as major means are used to determine the generality of participants' views and experiences regarding the nature and manifestations of the variables within which the research is centered. A base mean of $x$ $=2.0$, within assessing the adequacy of the variable manifestation assistance (with $x \geq 2.0$ ) or the inadequacy of such aid (when $\mathrm{x} \leq 2.0$ ) is taken as a threshold. 


\title{
DATA DISTRIBUTION ON STAFF DEVELOPMENT STRATEGIES
}

\author{
Table 4.5 Indictors on Mentoring
} Descriptive Statistics

\begin{tabular}{|c|c|c|c|c|c|}
\hline & $\mathbf{N}$ & Minimum & Maximum & Mean & Std. Deviation \\
\hline $\begin{array}{l}\text { Mentoring program are aligned with the Department's } \\
\text { business strategy for high performance. }\end{array}$ & 214 & 1.00 & 5.00 & 3.7009 & 1.33719 \\
\hline $\begin{array}{l}\text { New employees are supported in locating and } \\
\text { accessing organizational resources and staff. }\end{array}$ & 214 & 1.00 & 5.00 & 4.1215 & 1.07651 \\
\hline $\begin{array}{l}\text { The organization provides employees with job } \\
\text { specific training }\end{array}$ & 214 & 1.00 & 5.00 & 3.9533 & 1.22481 \\
\hline $\begin{array}{l}\text { Mentors and mentees have a clear understanding of } \\
\text { the program guidance, process and procedures. }\end{array}$ & 214 & 1.00 & 5.00 & 3.8084 & 1.40613 \\
\hline Development opportunities for mentors are important & 214 & 1.00 & 5.00 & 3.9159 & 1.38822 \\
\hline Valid N (listwise) & 214 & & & & \\
\hline
\end{tabular}

SPSS output, Version 26

Table 4.5 illustrates the result for the data distribution for mentoring, the results point out that indicators of mentoring all bear high and substantial mean values, resulting from the high mean scores for each of their statement items; this is suggestive of strong affirmative response to the construct from the respondents.

\section{Table 4.6 Indictors on Coaching Descriptive Statistics}

\begin{tabular}{|c|c|c|c|c|c|}
\hline & $\mathbf{N}$ & Minimum & Maximum & Mean & Std. Deviation \\
\hline $\begin{array}{l}\text { Leadership, coaching, interpersonal skills, and } \\
\text { professional growth opportunities for our workforce are } \\
\text { available and highly visible. }\end{array}$ & 214 & 1.00 & 5.00 & 3.1682 & 1.37370 \\
\hline $\begin{array}{l}\text { The workforce is supported in awareness and } \\
\text { understanding of the organization's values, vision, } \\
\text { mission, and goals }\end{array}$ & 214 & 1.00 & 5.00 & 3.6075 & 1.19276 \\
\hline $\begin{array}{l}\text { Senior and experienced staff shares skills and knowledge } \\
\text { with less experienced staff. }\end{array}$ & 214 & 1.00 & 5.00 & 3.8037 & 1.13369 \\
\hline $\begin{array}{l}\text { Innovation and technologies are promoted, and designed } \\
\text { to enhance the workforce and goals of the Department. }\end{array}$ & 214 & 1.00 & 5.00 & 3.6168 & 1.34020 \\
\hline $\begin{array}{l}\text { Support for knowledge transfer and the } \\
\text { interchange/exchange of information between members } \\
\text { of different organizations is promoted. }\end{array}$ & 214 & 1.00 & 5.00 & 3.8037 & 1.12537 \\
\hline Valid N (listwise) & 214 & & & & \\
\hline
\end{tabular}

\section{SPSS output, Version 26}

Table 4.6 illustrates the result for the data distribution for coaching within the organization, the results point out that indicators of coaching all bear high and substantial mean values, resulting from the high mean scores for each of their statement items; this is suggestive of strong affirmative response to the construct from the respondents. 
DATA DISTRIBUTION ON ORGANIZATIONAL PERFORMANCE

Table 4.7 Indicators on Growth Descriptive Statistics

\begin{tabular}{|c|c|c|c|c|c|}
\hline & $\mathbf{N}$ & Minimum & Maximum & Mean & Std. Deviation \\
\hline $\begin{array}{l}\text { We constantly emphasize and introduce } \\
\text { managerial innovations (e.g. computer-based } \\
\text { administrative innovations, new employee } \\
\text { reward/training schemes, new departments or } \\
\text { project teams, etc.). }\end{array}$ & 214 & 1.00 & 5.00 & 3.8598 & 1.19033 \\
\hline $\begin{array}{l}\text { New products and services often take us up against } \\
\text { new competitors. }\end{array}$ & 214 & 1.00 & 5.00 & 3.3551 & 1.40591 \\
\hline $\begin{array}{l}\text { Previous decisions are a very useful source of } \\
\text { information for current decisions }\end{array}$ & 214 & 1.00 & 5.00 & 3.4953 & 1.24375 \\
\hline $\begin{array}{l}\text { We have individuals dedicated to collecting and } \\
\text { internal dissemination of improvement } \\
\text { propositions from employees. }\end{array}$ & 214 & 1.00 & 5.00 & 3.5327 & 1.35880 \\
\hline $\begin{array}{l}\text { Employees are regularly trained to fulfil company } \\
\text { objectives in changing situation }\end{array}$ & 214 & 1.00 & 5.00 & 3.4860 & 1.27353 \\
\hline $\begin{array}{l}\text { Training programmes are provided to those who } \\
\text { frame the Performance appraisal System for } \\
\text { employees }\end{array}$ & 214 & 1.00 & 5.00 & 3.7103 & 1.32161 \\
\hline Valid N (listwise) & 214 & & & & \\
\hline
\end{tabular}

SPSS Output, version 26

Table 4.7 illustrates the result for the data distribution for corporate growth, the results point out that indicators of growth effect all bear high and substantial mean values, resulting from the high mean scores for each of their statement items; this is suggestive of strong affirmative response to the construct from the respondents.

Table 4.8 Correlation between Mentoring and Corporate Growth Correlations

\begin{tabular}{lllr|r} 
& & Mentoring & \multicolumn{1}{c}{$\begin{array}{c}\text { Corporate } \\
\text { Growth }\end{array}$} \\
\hline Spearman's rho & Mentoring & Correlation Coefficient & 1.000 & $.899^{* *}$ \\
\cline { 3 - 5 } & & Sig. (2-tailed) &. & .000 \\
\cline { 2 - 5 } & $\mathrm{N}$ & 214 & 214 \\
\cline { 2 - 5 } & Corporate Growth & Correlation Coefficient & $.899^{* *}$ & 1.000 \\
\cline { 3 - 5 } & & Sig. (2-tailed) & .000 &. \\
\cline { 3 - 5 } & $\mathrm{N}$ & 214 & 214 \\
\hline
\end{tabular}

**. Correlation is significant at the 0.01 level (2-tailed).

SPSS output, Version 26

Table 4.8 presents Spearman's rank order correlation run to find out the relationship between mentoring and corporate growth as reported by respondents. A strong positive correlation coefficient value was reported between mentoring and corporate growth statistically significant $\left(\mathrm{rho}=.899^{* *}, \mathrm{p}=.000<0.05\right)$ this suggests that there is significant relationship between the variables.

Decision: The null hypothesis $\left(\mathbf{H o}_{\mathbf{1}}\right)$ is rejected and we state that there is significant relationship between mentoring and corporate growth.

Ho. There is no significant relationship between coaching and corporate growth. 
Table 4.9 Correlation between Coaching and Corporate Growth. Correlations

\begin{tabular}{lllr|r} 
& & \multicolumn{1}{c|}{$\begin{array}{c}\text { Corporate } \\
\text { Growth }\end{array}$} \\
\hline Spearman's rho & Coaching & Correlation Coefficient & 1.000 & $.910^{* * *}$ \\
\cline { 3 - 5 } & & Sig. (2-tailed) & .000 \\
\cline { 2 - 5 } & $\mathrm{N}$ & 214 & $.010^{* *}$ \\
\cline { 2 - 5 } & Corporate Growth & Correlation Coefficient & .000 & 1.000 \\
\cline { 3 - 5 } & & Sig. (2-tailed) & 214 & 214 \\
\cline { 3 - 5 } & $\mathrm{N}$ & & \\
\hline
\end{tabular}

**. Correlation is significant at the 0.01 level (2-tailed). SPSS output, Version 26

Table 4.9 presents Spearman's rank order correlation run to find out the relationship between coaching and corporate growth as reported by respondents. A strong positive correlation coefficient value was reported between coaching and corporate growth which was statistically significant ( $\mathrm{rho}=.910 * *, \mathrm{p}=.000<0.05$ (alpha value) this suggests that there is significant relationship between the variables.

Decision: The null hypothesis $\left(\mathbf{H o}_{\mathbf{4}}\right)$ is rejected and we state that there is significant relationship between coaching and corporate growth.

\section{RELATIONSHIP BETWEEN MENTORING AND CORPORATE GROWTH}

The analysis assessed the impact of mentoring on corporate growth, with NAOC as case study. The result for our first hypothesis indicates that mentoring has significant and positive impacts on corporate growth. Mentoring serves a useful purpose in business growth and development. Today organizations face the challenge of adding value in a cost-effective manner. There is therefore the need to introduce processes that will contribute directly to the career development and corporate growth. The finding is in line with that of Ayodeji and Adebayo (2015) who finds that mentoring is a tool that offers immense benefits at minimal cost to the mentee and organization. Regardless of how a mentor and mentee are matched, etiquette and ethics demand that the relationship be conducted in a professional manner with consideration and respect for both individuals.

\section{RELATIONSHIP BETWEEN COACHING AND CORPORATE GROWTH}

Results of our fourth hypothesis reveals a positive relationship between coaching dimension of staff development and corporate growth. Coaching is a process of knowledge and skill transfer, it is one of the functions in human resource management that can make the difference between success and failure, because it contributes to making an organization more adaptable to changing and competitive environments (Palmer and Johnson, 2005; Becker, Hyland and Acutt, 2006). Coaching is a key technique for professional development with the organization. Coaching ensure that management does not lack the required skills whenever the need arises, by providing management with available talent even in the face of perturbations. Coaching allows managers to learn and to actively adapt resource management policies thereby reducing the likelihood of moving into unsustainable and undesirable development trajectories.

\section{CONCLUSION}

Having established that staff development is positively and significantly related to organizational performance, companies that continually support and encourage individual/group mentoring and coaching have better chances of improving organizational performance. They ought to also spend comprehensively in the teaching, coaching and mentoring of their workers. Mentoring and Coaching still serves as a competent resource of retaining important employees. Employees' abilities are improved through mentoring and coaching and this inspires retention especially where coaching schemes are tailored concerning employees' profession advancement in the firm.

\section{RECOMMENDATION}

i. Given the importance of coaching and mentoring, it is recommended that organizational practices be streamlined to increase coaching and mentoring by assigning or encouraging leaders to adopt subordinates and assign higher responsibilities aimed at seeing them develop. Managers or leaders here should be encouraged to get subordinates more involved in daily activities of the 
organizations business running and should be thoughtfully concerned about how well subordinates perform and develop in such endeavors.

ii. Organizations should be regular and consistent with coaching and mentoring sessions between senior management and subordinates and have a system that follows up and evaluates the success of these sessions. Employees should be afforded the opportunities to grow personally and professionally because when they feel competent to perform their job it increases the level of commitment and productivity.

\section{REFERENCES}

1. Ardishvili, A., Cardozo, S., Harmon, S., \& Vadakath, S. (1998). Towards a theory of new venture growth. Paper presented at the Babson Entrepreneurship Research Conference, Ghent, Belgium, 21-23.

2. Ayodeji, D. and Adebayo O. (2015.) E-mentoring: using computer medicated communication to enhance the mentoring process. Innovative Higher Education 26(3), 211-227.

3. Beardwell, C. and Holden E. (2001). Characteristics of effective organizations. Eric Moore, New York.

4. Becker, G., Bullock, R., and Batten, D. (2006). It's just a phase we're going through: A review and synthesis of $O D$ phase analysis. Group \& Organization Studies, 10(4), 383-412.

5. Bratton, H. and Gold, T. (2007). Organizational performance: One model or several? Organizational performance 6, 1-24.

6. Chandler, G. N., \& Hanks, S. H. (1993). Measuring the performance of emerging businesses: A validation study. Journal of Business Venturing, 8(5), 391-408.

7. Cravens, J. (2003). Online mentoring: Programs and suggested practices as of February 2001. Journal of Technology in Human Services, 21(1-2), 85-109.

8. Dubin, G. H. (1976). Balancing the logistics costof-service equation in an increasingly uncertain business environment. Journal of Transportation Management, 35.

9. Drucker, P. (2013). People and performance Routledge.

10. Etzioni, A. (1964). Modern organizations. Englewood Cliffs, New Jersey: Prentice Hall.

11. Hakkert, R., Kemp, R., \& Zoetermeer, S. (2006). An ambition to grow: A multidisciplinary perspective on the antecedents of growth ambitions. Eim Scales, 8-21.

12. Kimberly, J. R. (1976). Organizational size and the structuralist perspective: A review, critique, and proposal. Administrative Science Quarterly, 571597.
13. Krejcie, R. V., \& Morgan, D. W. (1970). Determining sample size for research activities. Educational and psychological measurement, 30(3), 607-610.

14. Mihaicz, D. (2012). The importance of organizational performance. Retrieved may 12, 2017 ,

fromHttp://www.Effectivemanagers.com/dwightmihalicz/the-Importance-ofOrganizationalPerformance,

15. Miller, D., \& Friesen, P. H. (1984). Organizations. A Quantum View. Englewood Cliffs.

16. Mullins, L. J. (2007). Management and organizational behaviour Pearson education.

17. Nankervis, A., Stanton, P., \& Foley, P. (2012). Exploring the rhetoric and reality of performance management systems and organizational performance-evidence from Australia. Research and Practice in Human Resource Management, 20(1), 40-56.

18. Pfeffer, J., \& Salanick, G. R. (1978). The external control of organizations: A resource dependence perspective. New York: Harper Row.

19. Price, A. (2016). The study of organizational performance. The Sociological Quarterly, 13(1), 64-83.

20. Richard, P. J., Devinney, T., Yip, G., \& Johnson, G. (2009). Measuring organizational performance: Towards methodological best practice. journal of management, 35(30), 718-804.

21. Salas, A. and Cammon B. (2001). Measuring organizational growth. Journal of Management, 24(2), 235-262.

22. Sirkin, H. L., Keenan, P., \& Jackson, A. (2005). The hard side of change management. Harvard Business Review, (October).

23. Ulrich, A. (2011). Introduction. In A. Uhl, \& L. A. Gollenia (Eds.), A handbook of business transformation management methodology. London: MPG Books Group.

24. Palmer, U. and Johnson, F. (2005). The Nigerian maritime sector is 50 years behind other nations. Ships and Ports bulleting (August 12).

25. Viner, G. (2011). Building organizational resilience for competitive advantage. Journal of Entrepreneurship, 3(4) 89-98.

26. Watzlawick, P. (1990). Reality adaptation or adapted reality? constructivism and psychotherapy. In P. Watzlawick (Ed.), Munchhausen's pigtail: Or psychotherapy \& reality - essays and lectures. New York: W.W. Norton \& Company.

27. Yuchtman, E., \& Seashore, S. E. (1967). A system resource approach to organizational performance. American sociological review, 891903. 